\title{
The metabolism of methionine in silage-fed sheep
}

\author{
BY MARGARET GILL* \\ Sheep Husbandry Department, Massey University, \\ Palmerston North, New Zealand \\ AND M. J. ULYATT \\ Applied Biochemistry Division, DSIR, Palmerston North, New Zealand
}

(Received 30 March 1978 - Accepted 20 November 1978)

\begin{abstract}
1. L-[U-14C]methionine was used to study methionine metabolism in sheep fed on untreated silage, silage treated with formaldehyde and untreated silage plus intraperitoneal infusion of $L$-methionine.

2. Over-all the values ranged from 0.43 to $0.86 \mathrm{mmol} / \mathrm{h}$ for methionine turnover rate, from I 3.3 to 19.9 for the percentage of methionine oxidized to carbon dioxide and from 245 to $1089 \mu \mathrm{mol}$ for methionine pool size.
\end{abstract}

There have been few quantitative studies on the metabolism of methionine in ruminants despite frequent suggestions that it is the first limiting amino acid for a variety of diets (e.g. Hutton \& Annison, 1972; Armstrong \& Annison, 1973; Harrison et al. 1973). Barry et al. (1973) showed that intraperitoneal injections of methionine increased voluntary intake and wool growth of sheep fed silage which suggests that silage supplies the tissues with insufficient methionine. For this reason the effect of an intraperitoneal infusion of L-methionine on methionine metabolism was studied in sheep fed on silage. Formaldehyde treatment of the silage enabled additional study of the effect of increased availability of protein to the tissues. Initially a $3 \times 3$ Latin Square design was attempted, but two of the three sheep had to be replaced during the experiment, thus precluding the use of statistical analysis. However, the data presented do give a preliminary quantification of methionine metabolism in ruminants.

\section{EXPER IMENTAL}

A detailed description of the rations and the methods of collection and analysis of digesta samples is given by Gill et al. (1978). The sheep used were mature New Zealand Romney Marsh wethers weighing $28-44 \mathrm{~kg}$.

\section{Design}

The experimental design chosen was a $3 \times 3$ Latin Square with three treatments (untreated silage, formaldehyde-treated silage and untreated silage plus an intraperitoneal infusion of approximately I g L-methionine/d) and three sheep per treatment. However, after the second replicate had been completed, two sheep were losing considerable quantities of duodenal fluid from around their re-entrant cannulas and had to be replaced for the third replicate. Therefore, a balanced Latin Square design was not achieved. Statistical comparisons between treatments were thus confounded by animal effects and hence no valid statistical analysis could be made.

\section{Collection of plasma and expired air samples}

Measurements of methionine metabolism were made using a continuous infusion of L-[U- $\left.{ }^{14} \mathrm{C}\right]$ methionine (New England Nuclear, Boston, Mass., USA) with no priming dose.

* Present address: The Grassland Research Institute, Hurley, Maidenhead, Berks SL6 5 LR. 
The infusion was made via a catheter inserted in the right jugular vein while blood was sampled through a catheter in the left jugular vein. The infusion solutions contained approximately $80 \mu \mathrm{Ci} \mathrm{L}-\left[\mathrm{U}-{ }^{14} \mathrm{C}\right]$ methionine in $200 \mathrm{ml}$ sterile saline (9 $\mathrm{g}$ sodium chloride/l) and were infused for $12 \mathrm{~h}$ at a rate of $16 \mathrm{ml} / \mathrm{h}$. During infusion the sheep was placed in a metabolism crate with its head enclosed in a Perspex respiration hood sealed by a rubber collar (Ulyatt et al. 1978). The carbon dioxide expired was measured with an infra-red gas analyser (Grubb Parsons, Newcastle-upon-Tyne, England). A portion of expired air was bubbled through I M-sodium hydroxide in a Dreschel wash bottle to absorb $\mathrm{CO}_{2}$ for measurement of its specific radioactivity. The wash bottles were changed and blood samples taken at $5,15,30$, $60,90,120,150,180,210,240 \mathrm{~min}$ after the start of the infusion and thereafter at hourly intervals for a further $8 \mathrm{~h}$. Blood samples ( $10 \mathrm{ml}$ ) were withdrawn into heparinized tubes and centrifuged at $6000 \mathrm{~g}$ for $20 \mathrm{~min}$ to separate plasma. Plasma protein was precipitated by an equal volume of sulphosalicylic acid solution ( $100 \mathrm{~g} / \mathrm{l})$. The protein precipitate was then removed by centrifugation at $6000 \mathrm{~g}$ for $15 \mathrm{~min}$ and the supernatant fraction stored at $-20^{\circ}$.

\section{Chemical analysis}

Plasma methionine concentrations were measured on a Jeol JLC 6AH (JEOL, Tokyo, Japan) amino acid analyser, using the specific sulphur amino acid procedure of Jeppsson \& Karlsson (1972). Radioactivity was determined on fractions of the column effluent, to enable calculation of methionine specific activity.

The specific activity of ${ }^{14} \mathrm{CO}_{2}$ was measured after precipitation as $\mathrm{Ba}{ }^{14} \mathrm{CO}_{3}$ with excess barium chloride. The precipitate was assayed for radioactivity in a Packard liquid scintillation counter using the gel scintillation method of Cluley (I962).

\section{Calculations}

The specific radioactivity of plasma methionine increased exponentially with time interval after start of infusion and reached a plateau $\left(\mathrm{SA}_{M \mathrm{E}}\right)$ after approximately $3 \mathrm{~h}$. The turnover rate $(F)$ of the methionine pool was calculated as follows (Shipley \& Clark, 1972):

$$
F=r / \mathrm{SA}_{\mathrm{ME}}
$$

where $r$ was the infusion rate of $\mathrm{L}-\left[\mathrm{U}-{ }^{14} \mathrm{C}\right]$ methionine. The methionine pool size $(Q)$ was calculated as: $Q=F / k$, where $k$ is the rate constant of efflux of the methionine pool. The rate constant $(k)$ was determined from the plot of $\log \left(\mathrm{SA}_{\mathrm{ME}}-\mathrm{SA}_{\mathrm{MT}}\right)$, where $\mathrm{SA}_{\mathrm{Mr}}$ was the specific activity of methionine at time $T$. Unfortunately because of large variation in methionine specific activity in some experiments during the first hour of infusion, $k$ could only be calculated for two sheep on each treatment.

The first infusion of $\mathrm{L}-\left[\mathrm{U}-{ }^{14} \mathrm{C}\right]$ methionine was continued for $24 \mathrm{~h}$ to determine the shape of the response curve for specific activity of expired ${ }^{14} \mathrm{CO}_{2}$. No clear plateau was reached within $24 \mathrm{~h}$ and there was a considerable increase in scatter of the points during the last ro $\mathrm{h}$. It was assumed that these effects were due to recycling of ${ }^{14} \mathrm{C}$ within the animal. Since the rate of increase in ${ }^{14} \mathrm{CO}_{2}$ specific activity also decreased markedly between I I and $\mathrm{I} 2 \mathrm{~h}$, for comparison between treatments, subsequent experiments were limited to $12 \mathrm{~h}$. Equilibri um ${ }^{14} \mathrm{CO}_{2}$ specific activity was calculated as the average of the last $3 \mathrm{~h}$ of the infusion. The proportion of methionine oxidized to $\mathrm{CO}_{2}$ was calculated as

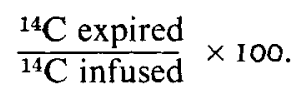

Methionine available for absorption (Table 1) was calculated as methionine entering the duodenum plus the amount infused intraperitoneally. 
Table 1. Measurements of methionine metabolism in sheep fed on pasture silage, pasture silage treated with formaldehyde, or pasture silage supplemented with an intraperitoneal infusion of L-methionine

\begin{tabular}{|c|c|c|c|c|}
\hline & & Silage & & \\
\hline & Untreated & $\begin{array}{l}\text { Formaldehyde } \\
\text { treated }\end{array}$ & $\begin{array}{l}\text { Untreated and } \\
\text { intraperitoneal } \\
\text { methionine }\end{array}$ & S.E. \\
\hline $\begin{array}{l}\text { Methionine available for absorption* } \\
(\mu \mathrm{mol} / \mathrm{min})\end{array}$ & $4 \cdot 2$ & 7.0 & 9.8 & $1 \cdot 20$ \\
\hline $\begin{array}{l}\text { Absorbable methionine (\% total } \\
\text { amino acids entering the duodenum) }\end{array}$ & $2 \cdot 1$ & $2 \cdot 3$ & 44 & 0.87 \\
\hline $\begin{array}{l}\text { Plasma methionine concentration } \\
(\mu \mathrm{mol} / \mathrm{l})\end{array}$ & $8 \cdot 3$ & $1 I \cdot 3$ & 14.5 & $3 \cdot 15$ \\
\hline $\begin{array}{l}\text { Methionine oxidized to carbon } \\
\text { dioxide }(\%)\end{array}$ & $15 \cdot 3$ & 15.6 & 19.0 & $1 \cdot 37$ \\
\hline $\begin{array}{l}\text { Methionine turnover rate } \\
(\mu \mathrm{mol} / \mathrm{min})\end{array}$ & $8 \cdot 5$ & $10 \cdot 7$ & I $3 \cdot 0$ & $I \cdot 45$ \\
\hline Methionine pool size $\uparrow(\mu \mathrm{mol})$ & 562 & 605 & 1026 & - \\
\hline
\end{tabular}

\section{RESULTS AND DISCUSSION}

Methionine metabolism was studied with the use of $\mathrm{U}^{14} \mathrm{C}$-labelled methionine. The factors estimated are given in Table I, together with details of plasma methionine concentration and the flow of methionine into the duodenum. The small number of animals used in this experiment, and the problems of animal replacement as mentioned previously, precluded the use of statistics in analysing response to the two treatments. However, published information on methionine metabolism in ruminants is limited and the total range of values presented in Table I do give a preliminary quantification of such factors.

Earlier studies on methionine metabolism in ruminants have been primarily concerned with assessment of methionine requirement. These studies have been mainly confined to estimating requirement by measuring response in plasma methionine concentration to postruminal infusion of increasing amounts of methionine (Nimrick et al. 1970; Wakeling et al. 1970; Reis et al. 1973; Williams \& Smith, 1974). The use of ${ }^{14} \mathrm{C}$-labelled methionine to measure the percentage of methionine oxidized to $\mathrm{CO}_{2}$ and thus estimate requirement, has been reported by Armstrong \& Annison (1973), Annison (1975) and Lewis \& Mitchell (1976). These reports refer to work by R. M. Mitchell, D. Lewis \& E. F. Annison (unpublished results) and since detailed results were not given, no comparison can be made with the values reported in Table $I$.

In all these studies the response to increased methionine availability was defined by two straight lines. In the present study the response to increased methionine availability appeared to be linear. However, since methionine availability was confounded with an increase in the percentage of methionine in total amino acids (Table I) the results of the two treatments and control cannot be used to define a single response curve. The difference between treatments in percentage of methionine in total duodenal amino acids is a reflection of the different mechanisms by which formaldehyde treatment and intraperitoneal methionine produced the responses reported by Barry et al. (1973). Both treatments increased methionine availability, but while formaldehyde treatment increased the flow of total amino acids into the duodenum, intraperitoneal methionine had no effect on total amino acids (Gill, 1976). 
The percentage of methionine which was oxidized to $\mathrm{CO}_{2}$ ranged from 13.3 to 19.9. J. C. Mathers \& E. L. Miller (personal communication) have obtained similar values with calves using $\left[{ }^{14} \mathrm{C}\right]$ methionine. Their values ranged from $\mathrm{I} 0$ to $18 \%$ under conditions of low methionine supply increasing to $30 \%$ with methionine infusion.

The increases in the rate of turnover of methionine agree closely with the increases in the amount of methionine available for absorption. Formaldehyde treatment of the silage increased the methionine available for absorption by $2.8 \mu \mathrm{mol} / \mathrm{min}$, with a corresponding increase in turnover rate of $2 \cdot 2 \mu \mathrm{mol} / \mathrm{min}$. Intraperitoneal infusion of methionine supplied an additional $5.6 \mu \mathrm{mol} / \mathrm{min}$ giving an increase in turnover rate of $4.5 \mu \mathrm{mol} / \mathrm{min}$. Wolff \& Bergman (1972) measured turnover rates in arterial plasma for alanine, aspartate, glutamate, glycine and serine. When predicted absorption of the individual amino acids is taken into account, the values obtained for methionine in the present experiment are of a similar magnitude or slightly higher than those obtained by Wolff \& Bergman (1972).

The size of pool which this turnover rate respresents was also measured, although owing to the variability in specific activity values before the plateau at $2 \mathrm{~h}$, values for only two of the three sheep on each treatment could be calculated. The size of methionine pool ranged from 245 to $1089 \mu \mathrm{mol}$, and using the rate-constant $(k)$ to calculate turnover time $(1 / k)$ (Shipley \& Clark, 1972) this pool turned over in approximately I h. The total plasma pool of free methionine was estimated to be approximately $20 \mu \mathrm{mol}$, based on the assumption that plasma volume is $5 \%$ of body-weight (Harper, 1964). The isotope kinetic values thus refer to a labile methionine pool considerably greater than free plasma methionine.

In conclusion, this study provides a preliminary quantification of methionine metabolism in ruminants. In particular, it emphasizes the small magnitude of factors associated with methionine metabolism and hence the need for increasingly sensitive methods for studying methionine.

The receipt of a Commonwealth Scholarship by M. G. is gratefully acknowledged. The authors would also like to thank Drs G. W. Butler and R. W. Bailey (directors of Applied Biochemistry Division, DSIR, Palmerston North) for the provision of facilities, Messrs B. S. Henderson and I. D. Shelton for technical assistance, Dr J. E. Wolff and Mr P. R. Jenkins for enabling measurement of methionine specific activities to be conducted at Ruakura A.R.C., Hamilton, and Dr T. N. Barry (Invermay Research Centre, Mosgiel) for supplying the silage.

\section{REFERENCES}

Annison, E. F. (1975). Tracer Studies on Non-Protein Nitrogen for Ruminants, p. 141. Vienna: Internationa Atomic Energy Agency.

Armstrong, D. G. \& Annison, E. F. (1973). Proc. Nutr. Soc. 32, 107.

Barry, T. N., Fennessy, P. F. \& Duncan, S. J. (1973). N.Z. Jl agric. Res. 16, 64.

Cluley, H. J. (1962). Analyst, Lond. 87, 170.

Gill, M. (1976). A study of the amino acid status of sheep fed silage, with particular reference to methionine. Ph D Thesis, Massey University, New Zealand.

Gill, M., Ulyatt, M. J. \& Barry, T. N. (1978). N.Z. Jl agric. Res. (In the Press.)

Harper, A. E. (1964). In Mammalian Protein Metabolism, vol. 2, p. 87 [H. N. Munro and J. B. Allison, editors]. London: Academic Press.

Harrison, D. G., Beever, D. E., Thomson, D. J. \& Osbourn, D. F. (1973). J. agric. Sci., Camb. 81, 39 I.

Hutton, K. \& Annison, E. F. (1972). Proc. Nutr. Soc. 31, 15 I.

Jeppsson, J. O. \& Karlsson, I. M. (I972). J. Chromat. 72, 93.

Lewis, D. \& Mitchell, R. M. (1976). In Protein Metabolism and Nutrition, p. 417 [D. J. A. Cole, K. N. Boorman, P. J. Buttery, D. Lewis, R. J. Neale and H. Swan, editors]. London, Boston: Butterworths. Nimrick, K., Hatfield, E. E., Kaminski, J. \& Owens, F. N. (1970). J. Nutr. 100, 1293.

Reis, P. J., Tunks, D. A. \& Downes, A. M. (1973). Aust. J. biol. Sci. 26, 249. 
Shipley, R. A. \& Clark, R. E. (1972). In Tracer Methods for in vivo Kinetics, p. 239. New York and London: Academic Press.

Ulyatt, M. J., Webster, D., Henderson, B. S. \& Egan, A. R. (1978). N.Z. Jl agric. Res. (In the Press.)

Wakeling, A. E., Lewis, D. \& Annison, E. F. (1970). Proc. Nutr. Soc. 29, 60A.

Williams, A. P. \& Smith, R. H. (1974). Br. J. Nutr. 32, 42 I.

Wolf, J. E. \& Bergman, E. N. (1972). Am. J. Physiol. 223, 455. 